\title{
Advice for Infallibilists: DIVORCE and RETREAT!
}

\author{
Anthony Robert Booth ${ }^{1}$
}

Received: 1 April 2016 / Accepted: 28 April 2017 / Published online: 15 May 2017

(C) The Author(s) 2017. This article is an open access publication

\begin{abstract}
This paper comprises a defence of Infallibilism about knowledge. In it, I articulate two arguments in favour of Infallibilism, and for each argument show that Infallibilism about knowledge does not lead to an unpalatable Scepticism if justified belief is neither necessary nor sufficient for knowledge, and if Fallibilism about justified belief is true.
\end{abstract}

Keywords Epistemic justification $\cdot$ Knowledge $\cdot$ Fallibilism $\cdot$ Scepticism

\section{Introduction}

This paper comprises a defence of Infallibilism about knowledge. In it, I articulate two arguments in favour of Infallibilism, and for each argument show that Infallibilism about knowledge does not lead to an unpalatable Scepticism if justified belief is neither necessary nor sufficient for knowledge, and if Fallibilism about justified belief is true. I begin by formulating the kind of Infallibilism I want to defend and contrast it to other possible formulations of Infallibilism, Sect. 2. In Sect. 3, I articulate and motivate DIVORCE (the view that justified belief is neither necessary nor sufficient for knowledge) and RETREAT (the view that justified belief is fallible, where knowledge is not). In Sects. 3, and 4 I put forward two arguments for Infalliblism about knowledge (when DIVORCE and RETREAT are true): the Argument from Madness, and the Argument from Purism.

$\triangle$ Anthony Robert Booth

a.r.booth@sussex.ac.uk; arbooth@fastmail.fm

1 Department of Philosophy, University of Sussex, Brighton BN1 9QN, UK 


\section{Different infallibilisms}

The term 'Infallibilism' can mean many different things. I here discuss a few of these with a view to articulating the kind of Infallibilism I wish to defend in this paper. To start with, and to paint with broad brush-strokes, we can distinguish between Infallibilism about justified belief (or 'epistemic justification') and Infallibilism about knowledge. Infallibilism about knowledge is often thought of along the following lines:

\section{Infall $_{\mathrm{k}} \mathrm{S}$ knows that $p$ only if S's evidence entails that $p$.}

This is the formulation, for instance, used by Stanley (2005). I think this formulation is quite close to Lewis': "Subject $\mathrm{S}$ knows proposition $P$ iff $P$ holds in every possibility left uneliminated by $S$ 's evidence" (Lewis 1996, p. 551). Lewis here defines Infallibilism in terms of a bi-conditional, whereas Infall $_{\mathrm{k}}$ does not. I do not think much hangs on this for the purposes of this paper, but I will be working with the weaker formulation (in terms of an only if) just to be safe.

Dylan Dodd defines Infallibilism as follows: "If a subject $S$ knows $p$, then the epistemic probability of $p$ for $S$ is 1 " (Dodd 2011, p. 665). I think this can legitimately be considered a way of understanding Infall $_{k}$; however, I would like to work with a notion of Infallibilism that is as neutral as possible- Infall $\mathrm{k}_{\mathrm{k}}$ is neutral as regards whether S's evidence is S's subjective or objective evidence, and as regards whether S's evidence is to be understood in terms of epistemic probability.

One could then define Infallibilism about epistemic justification along similar lines, viz.:

Infall $_{\mathrm{j}} \mathrm{S}$ is justified in believing that $p$ only if $\mathrm{S}$ 's evidence entails that $p$.

However, some have labelled "Infallibilism' the view that it is impossible to have a justified, false belief.

Infall $_{\mathrm{j}} * \mathrm{~S}$ is justified in believing that $p$ only if $p$.

The falsity of Infall $_{j} *$ has been until fairly recently been the received view, where it nowadays has some supporters (cf. Sutton 2005, 2007; Littlejohn 2012; and notably (if not always explicitly) Williamson 2000). ${ }^{1}$ Littlejohn (2012, p. 122) calls this position "factivity"; that might make us think that the view is somewhat different from Infallibilism, since it seems uncontroversial to think that knowledge is factive, but not infallible. Still, since Infall $\mathrm{j}_{\mathrm{j}}$ entails Infall $_{j} *$ (if the latter is about objective evidence) then perhaps calling it 'Infallibilism' is not wholly inappropriate. Nonetheless, it seems to me that Infall ${ }_{j}$ captures what people mean by 'Infallibilism' with less controversy, so will be working with that definition in this paper.

\footnotetext{
${ }^{1}$ According to Williamson, only known (so true) propositions can justify belief (though he claims to allow of justified, false belief, since these beliefs can fail to be known but are based on known propositions). For criticism, see McGlynn (2013), Kelp (2011).
} 
This paper is a defence of Infall $_{\mathrm{k}}{ }^{2} \mathrm{I}$ argue that there are strong arguments in its favour if we reject Infall $l_{j}$ and if we do so via endorsing what I will call DIVORCE and RETREAT. I move now to articulating the latter two views.

\section{If DIVORCE and RETREAT, then Infall $_{k}$ is defensible}

In this section, I argue that Infall $_{k}$ is less vulnerable than has been assumed to the usual challenge it faces from Scepticism if both the theses I am going to call DIVORCE and RETREAT are true. That is, it can embrace the Sceptical challenge at a more palatable cost-more palatable than merely conceding, without caveat, that we know very little. ${ }^{3}$ Let us start with a look at DIVORCE.

\subsection{DIVORCE}

According to several philosophers the following thesis is true: ${ }^{4}$

DIVORCE Epistemic justification and knowledge are logically independent notions. Epistemic justification is neither necessary nor sufficient for knowledge.

That several philosophers have defended the view should be enough to (minimally) motivate the view for the purposes of my discussion. My aim is to show how endorsing DIVORCE and what I will call RETREAT can help us deal with the Sceptical puzzle. But those who deny DIVORCE seem to find the view so offensive, ${ }^{5}$ that I think it's worth motivating it a bit more here, by offering a simple argument for it. Further, as I hope to show in the next section, the manner in which I defend DIVORCE will show that the combined forces of DIVORCE and RETREAT make for an effective strategy for dealing with the Sceptic. Here is my case for DIVORCE:

(i) It is possible that $\mathrm{S}$ is justified in believing that $\mathrm{p}$ and that it is veritically ${ }^{6}$ lucky for $\mathrm{S}$ that $\mathrm{p}$. [Premise]

(ii) If $\mathrm{S}$ knows that $\mathrm{p}$, it cannot be veritically lucky for $\mathrm{S}$ that $\mathrm{p}$. [Premise]

\footnotetext{
${ }^{2}$ I do not here pretend to have given an exhaustive list of all the different possible Infallibilisms there could be [for instance, I don't discuss the interesting distinction made in Kvanvig (2014) between what he calls epistemic and aletheic Infallibilism]. The purpose of the discussion is just to try to zero in on the thesis that I want to defend, and to make a case for the propriety of calling it Infallibilism. I remain open to the possibility that it isn't really Infallibilism, even though it is permissible to call it that.

3 Williamson (2000) holds something like my Infall $k_{k}$ and claims that it does not lead to Scepticism. Dodd (2007) argues that Williamson must, after all, embrace Scepticism (Littlejohn 2008 replies). I will not here access whether or not Williamson indeed succeeds in evading the Sceptic (or whether someone else such as Neta 2011 does) — what I am primarily interested in here is to put together a new (or certainly for some reason underrepresented way) of being an Infallibilist and responding to the Sceptic.

${ }^{4}$ For example (inter alia) Bonjour (2003), Booth (2011, 2014); Foley (2004); Kaplan (1985), Lockie (2014).

5 I'm afraid that 'offensive' is the right word to describe how these philosophers consider this view.

${ }^{6}$ Where 'veritic luck' is luck that S's belief is true, given S's evidence. This in contrast with evidential luck—luck that $\mathrm{S}$ ends up having evidence that her belief is true—or doxastic luck—luck that $\mathrm{S}$ believes that $\mathrm{p}$ (see Pritchard 2005).
} 
(iii) The justification condition is not a good anti-veritic-luck condition on knowledge. [from (i), (ii)]

(iv) Either the justification condition is redundant as a condition on knowledge, or it serves some other function than ruling out veritic luck. [corollary of (iii)]

(v) If the justification condition is not an anti-veritic-luck condition, then DIVORCE. [Premise].

(vi) DIVORCE. [from (v), (iii)]

I think premises (i) and (ii) can be defended by merely invoking Gettier cases [for more support that this is what Gettier cases really teach us see (Zagzebski 1994)]; premise (iii) I think can be defended by bringing to mind better, tailor-made anti-luck (modal) conditions, such as Safety. Here is Pritchard's definition of Safety:

S's belief is safe iff in most near-by possible worlds in which S continues to form her belief about the target proposition in the same way as in the actual world, and in all very close near-by possible worlds in which $\mathrm{S}$ continues to form her belief about the target proposition in the same way as in the actual world, the belief continues to be true. (Pritchard 2007, p. 292).

It is clear that any veritic luck that is ruled out by a justification condition on knowledge will be ruled out by Safety, even if it is the case that a Safe belief can nonetheless be Gettiered. Safety is a stronger anti-luck condition than is justification since it is explicitly a modal condition, while justification is not explicitly so. One might be minded to make Safety a condition on justification, but this has typically not been what epistemologists have done. Rather, in light of the availability of anti-luck modal conditions they have either eschewed the justification condition all together (as in so-called 'radical externalism') or have proposed and an analysis where justification is an extra condition alongside the modal anti-luck conditions, in a so-called 'JTB+' analysis. In a JTB + analysis, since the ' + ' condition (the modal condition) is doing all the work we need a condition in the analysis of knowledge to do by way of ruling out veritic luck, the justification condition must be motivated by something other than the thought that knowledge is incompatible with veritic luck. But in an analysis where justification is left out altogether, we have the intuition that not all the normative conditions on belief have been articulated - that is, that were a belief to have met the modal condition (and is true), we nonetheless feel that some normative condition on belief has not been met if the belief is not justified.

I think that premise ( $\mathrm{v}$ ) is the substantive premise in the above argument. My support for (v) is not going be completely convincing here, but I hope do enough to motivate its consideration. So what else could a justification condition be there to do, if not address an anti-veritic-luck intuition? It seems to me that the best account is that it addresses what can be called a "deontic intuition"7 with respect to our beliefs-that we feel that our beliefs ought to be justified. There is something very wrong with a believer who only has unjustified beliefs. So that if we eschew justification altogether from an analysis of knowledge, we seem to be violating an intuition: the deontic intu-

7 C.f. Booth (2011). 
ition. ${ }^{8}$ But this intuition is independent from any account of knowledge - it is about the normative conditions of correct belief: it concerns what we ought to believe. Or, put differently, it is only on the substantive assumption that justification is necessary for knowledge, that the deontic intuition is also an intuition that concerns knowledge. But, obviously enough, this is the very issue under consideration here. So if the opponent of DIVORCE cannot find any other reason than the fact of our having a deontic intuition to motivate her thesis, then it seems to me that we should consider DIVORCE to be at least plausible. ${ }^{9}$

However, the opponent of DIVORCE could insist that we have a 'brute' intuition that justification (deontologically construed) is necessary for knowledge. I say 'deontologically construed' given that we have ruled out that a justification condition is there to address an anti-veritic-luck intuition. We consider paradigm cases of knowledge, and it just seems to many of us that all these cases are also cases of (deontically) justified belief. Let's call this the Knowledge is Deontic Intuition (KIDI) intuition, to be contrasted to the Deontic Intuition (DI).

DI: We ought to have justified beliefs.

KIDI: Deontic Justification is necessary for Knowledge.

I think two points are in order here. First, the appeal the KIDI does not look like giving us strong independent reason for denying DIVORCE, since to appeal to KIDI just is to claim that you find the denial of DIVORCE intuitive. And, again, the claim that Deontic Justification is necessary for knowledge is the claim that is supposed to be the object of investigation. So one might then be minded to supplement this thought via appeal to considerations of parsimony: that the best unified theory of epistemic justification and theory of knowledge will be simpler, or more theoretically elegant, than two separate theories: one theory of epistemic justification, and one theory of knowledge. ${ }^{10}$ However, and this is my second point here, I think that KIDI entails DI, but not vice-versa (assuming that knowledge is possible). This is because if you have the KIDI, you might then think something like:

- $\mathrm{S}$ knows that $\mathrm{p}$ only if it is permissible for $\mathrm{S}$ to believe that $\mathrm{p}$.

$-\mathrm{S}$ knows that $\mathrm{p}$ only if $\mathrm{S}$ has a right to believe that $\mathrm{p}$.

$-\mathrm{S}$ knows that $\mathrm{p}$ only if $\mathrm{S}$ is blameless in believing that $\mathrm{p}$.

\footnotetext{
8 We might think instead that it is to take care of the thought that knowledge is incompatible with what Pritchard calls 'reflective luck' which is explained as follows “...we don't just want agents to be forming beliefs in such a way that we can rely on the truth of those beliefs, we also want agents to be cognitively responsible for their beliefs, and this is only possible if they form beliefs in such a way that are more than just safe" (Pritchard 2005, p. 184). But if the above is the explanation for why knowledge is thought to be incompatible with reflective luck, then the explanation looks very much like (I would say is identical to) what I call the 'deontic intuition' above.

9 We might say that the philosopher who investigates epistemic justification in a way that is not at all related to a project about how we are to understand knowledge is not really doing epistemology. I disagree, but I think the disagreement is merely a verbal one. I don't really care whether investigation is called epistemology, but just that people who think of themselves as epistemologists can find the idea of investigating the concept (taken independently from an investigation on knowledge) crucial.

10 Anecdotally, it is this last consideration that most of deniers of DIVORCE that I have personally encountered have felt to have most sway with them.
} 
If you are not a Sceptic, and you think any of those claims are true, ${ }^{11}$ then you must think that at least some beliefs are impermissible, or that there are some beliefs we have no right to believe, or that there are some beliefs that are blameworthy. This entails the claim that there are beliefs that you ought to have and there are beliefs that you ought not to have: to say that a belief is impermissible (for instance) is to say that one ought not to have it. And if you have the KIDI then you think that epistemic justification is to be construed in these deontic terms. So you think:

- Justified belief is permissible belief.

- There are beliefs you ought to have and beliefs that you ought not to have.

When you aggregate these two claims, you get the claim that you ought to have justified beliefs ( since those are the permissible beliefs, that you ought to have). In other words, you end up endorsing the DI. But the DI is about belief not knowledge, so is only about knowledge on the assumption that justification is necessary for knowledge. Since I do not think we are entitled to assume that here, I think this makes DI the logically weaker of the two intuitions, in that KIDI entails DI, but DI does not entail KIDI. So the DI is the epistemically more basic intuition. This being the case, a theory which posits (or relies on) only the DI is simpler than a theory that posits the KIDI and DI, and so considerations of parsimony decree that we should prefer the former. In other words, perhaps surprisingly, considerations of parsimony end up supporting DIVORCE and not its denial.

Now, given the logical relationship between the KIDI and the DI that I've just illustrated, we should predict that people will conflate the two intuitions, and errantly (hastily) move from the DI to the KIDI. This could potentially explain away people's having the KIDI-especially given the long history of the idea that justification is necessary for knowledge, and the thought that we ought not to leave theorising about justification out of epistemology. Though, of course, the denier of DIVORCE could just dig her heels in, and insist she has the KIDI without making this hasty generalisation. But here she's effectively conceding that she has run out of arguments, and so I take this to make DIVORCE at least plausible - a thesis worth considering. That's all I am trying to establish here.

\subsection{RETREAT}

There are many ways of being a Sceptic. But one quite general Sceptical strategy is this: show that S's putative "knowledge" that $p$ fails to rule out the epistemic possibility of not $p$. You don't really know that you are reading this paper if your evidence ${ }^{12}$ makes it permissible for you to think that it is possible that you are merely dreaming that you are reading this paper; you don't really know that you are reading this paper if your evidence makes it permissible for you to think it possible that someone is deceiving you into thinking that you are reading this paper, and so on.

\footnotetext{
${ }^{11}$ If KIDI entails the denial of DIVORCE only if Scepticism, then so much the worse for the denial of DIVORCE.

12 I'm using 'evidence' very broadly here to denote anything that might give S's belief that p positive 'epistemic status'.
} 
How might we respond to this kind of Sceptical threat?

It is generally accepted that if we respond by construing knowledge such that one cannot know and our evidence makes it permissible to believe that such possibilities obtain (that is, embrace Infallibilism) then we have given in to the Sceptic. It would mean that the standards for knowledge would be impossibly high, such that we can only warrantedly claim to know very little: our evidence is hardly ever that good. Impossibly high, that is, as against our pre-theoretical, ordinary standards for knowledge attribution. Some people have argued that we should then accept Scepticism, and not reject Infallibilism. According to Dodd (2011) for instance, the price for denying Infallibilism is as high as denying Scepticism; as he puts it: "even if infallibilism isn't cost free, it's cheaper that fallibilism" (Dodd 2011, p. 684) (cf. Unger 1975 for a similar line).

Another, much more popular, way to respond to the Sceptical threat is to deny Infallibilism. That is, deny that we need to rule out the possibility of error in order to know. Even if this looks somewhat counter-intuitive, it is better than accepting Scepticism; as David Lewis famously put it: "It demands less frequent corrections of what we want to say. So, if forced to choose, I choose fallibilism. (And so say all of us)" (Lewis 1996, p. 550).

A third way, which is broadly the way I want to follow here, is to appeal to what Crispin Wright (1991) has called "Russellian Retreat". The idea, found in Russell (1912), is that the lesson we ought to learn from epistemology is that we do not know much at all, and that we must content ourselves with probability, defeasibility and inconclusive justification. ${ }^{13}$ The underlying thought being that it is ok to accept the Sceptical conclusion that we do not know many of the things we thought we knew, since we can still claim to believe those things with justification. ${ }^{14}$ As such, we can embrace the Sceptical challenge, but at a palatable cost, since we can retain the idea that our beliefs may be nonetheless (defeasibly) justified even if they are not items of knowledge.

Clayton Littlejohn argues that because it is impossible for you to tell whether you justifiably believe that $p$ (in a way that falls short of knowledge) or whether you know that $p$, taking it to be impossible for you to know that $p$ will entail that you cease to believe that $p$. As he puts it: "It is impossible to retreat without abandoning belief, so the point of justification cannot be to steer us towards a more easily attainable goal than knowledge" (Littlejohn 2012, p. 3). ${ }^{15}$ However, the Sceptic and the proponent of RETREAT does not need to claim that knowledge is impossible. They merely need to claim that, for any particular case, knowledge is highly unlikely given how difficult knowledge is to get (since only infallible knowledge is knowledge). As such, it is possible to retreat without abandoning belief. The person making the retreat could reason as follows: for all I know, $p$ is in principle knowable, but since it is very unlikely that I have met the very stringent demands of knowledge, and since

\footnotetext{
13 Though as McGlynn (2013) points out, Russell himself seems to be a bit ambivalent about taking up the maneuver.

14 Cf. also Kaplan (1985).

15 Cf also Adler (2002), Huemer (2007), Sorensen (1988), Williamson (2000).
} 
whether I really know is counterprivate to me anyway, the best I can do is to ask myself whether my belief that $p$ is epistemically reasonable, and conclude that it is. Thinking that a knowable proposition is epistemically reasonable to believe in no way prevents me believing it, so I believe it. So it is possible to believe that $\mathrm{p}$ and believe that it is likely that one does not know that $\mathrm{p}$-we can retreat without abandoning belief. Now, it may be true that certain Sceptical arguments do have the aim of showing that knowledge is impossible. But here we are merely responding to Scepticism as generated by embracing Infallibilism, and that just makes knowledge much less common than we ordinarily think.

Note that Russellian Retreat as formulated above does not entail DIVORCE; the general Sceptical strategy might not rule out the possibility of our having justified beliefs, but that does not mean that justification is not necessary (or sufficient) for knowledge. I do not think, however, that we can adequately respond to Scepticism by Russellian Retreat without also endorsing DIVORCE.

To see this, let's understand the Retreat as the following claim.

RETREAT: Infall $\mathrm{j}_{\mathrm{j}}$ is false and Infall $_{\mathrm{k}}$ is true.

The advantage of understanding RETREAT as above is that it provides an explanation as to why justification is immune to the Sceptical challenge while acknowledging its draw: viz. we need not be Infallibilists about justification, although we must be Infallibilists about knowledge. Justification is immune from the challenge because it is fallible, but Scepticism is appealing because it does indeed show that we know less than we ordinarily thought. ${ }^{16}$ As such, we can at least partly embrace the Sceptical challenge, but do so in a less costly fashion (i.e. we need not abandon the possibility of justified belief).

The crucial thing I want to say is that by embracing both DIVORCE and RETREAT, we make the strategic retreat manoeuvre more effective. Wright thinks that once you accept that the Sceptic's arguments have to address warrant or justification as well as knowledge, on pain of falling prey to Russellian Retreat, you can't coherently formulate the Sceptical challenge and respect a certain constraint he sets out. ${ }^{17}$ I don't want to take issue with Wright's argument here, but in case his other constraint (or his argument that Scepticism cannot meet both constraints) is proved controversial, it is worth noticing that my way of arguing for RETREAT, via DIVORCE will yield a different and more direct way of dealing with the Sceptic. This is because if DIVORCE is true, the Sceptic cannot easily generalise her arguments about knowledge to address epistemic justification: if the reason epistemic justification figures in epistemology is to address a deontic constraint on belief (we ought to have justified beliefs) that is independent from any constraint on knowledge, then whether or not our evidence has eliminated the possibility that we are in a Sceptical scenario is not a relevant consideration when

\footnotetext{
16 Littlejohn (2013) has further argued that the aim/constitutive norm of belief is knowledge, not truth, and that this puts pressure on the viability of defensive moves like the Russelian Retreat. Luckily, I think that Littlejohn's arguments do perhaps show that truth is not the aim of belief, they do not discriminate over whether Knowledge instead of Justified, True Belief is the aim of belief. As such, his arguments do not really address my ends here. For further criticism of this and other lines of "knowledge-first" attack on Russelian Retreat, see McGlynn (2012, 2013).

17 Namely, that the Sceptical challenge needs to address both our second-order and first-order beliefs.
} 
attributing justification. What determines whether or not $\mathrm{S}$ is justified in believing that $\mathrm{p}$, for the defender of DIVORCE, has to do with whether $\mathrm{S}$ has done all that she can with respect to attaining a true belief that $\mathrm{p}$. The Sceptic may still insist that we would not demand that our beliefs be justified if we did not think that justification (doing all we can) was a path to truth (and this last thing, of course, is what the Sceptical challenge aims to throw into question). Yet the defender of DIVORCE is going to insist that we do make that demand, independently of whether or not a given justification is a path to truth. And this is because (to re-iterate the argument in Sect. 3.1 for DIVORCE) we make that demand even in cases where we have secured some mechanism that does guarantee that our belief will be true (for instance, we have ruled out the possibility of veritic luck by satisfying a modal condition such as Safety). It is because justification's fallibility is underwritten by this consideration-that we demand justification to satisfy an independent deontic constraint on belief - that makes its plausibility immune from the Sceptical challenge. ${ }^{18}$ Further, since RETREAT allows Infallibilism about knowledge, it gives us the means to provide a diagnosis of the appeal of Scepticism and an exposé of it. ${ }^{19}$

Put differently, the trouble with standing defences of RETREAT is that they allow the Sceptic to generalise her arguments about knowledge to justification. Endorsing DIVORCEand RETREAT blocks the Sceptic from making this move. As such, since she can shield epistemic justification from the Sceptical argument, we can make an (at least partly) effective tactical retreat while acknowledging its draw.

This, I will argue, is borne out in the following arguments for Infallibilism that I want to discuss.

The Argument from Madness

The Argument from Purism ('no' to pragmatic encroachment)

For each of these arguments I will show that they are most strong as arguments for Infall $_{k}$ and that if RETREAT is true, then Infall $_{k}$ can (at least partly) deal with the threat from Scepticsm via a tactical retreat (Infall $\mathrm{k}_{\mathrm{k}}$ and RETREAT are, of course, compatible). As such, accepting Infallibilism is not as repugnant a position as it might otherwise be considered.

\section{The argument from madness}

Here is Lewis' argument for Infallibilism: Fallibilism sounds mad!!

If you claim that $S$ knows that $p$, and yet you grant that $S$ cannot eliminate a certain possibility in which not-p, it certainly seems like you have granted that $\mathrm{S}$ does not know after all that $\mathrm{p} . .$.

If you are a contented fallibilist, I implore you to be honest, be naïve, hear it afresh. 'He knows, yet he has not eliminated all possibilities of error.' Even

\footnotetext{
18 Incidentally, this will also knock out certain Sceptical arguments directed at justification; for instance it knocks out the vital premiss "If I can't know anything about the external world, then I can't have any reason for believing anything about it" (Unger 1975 p. 37) [Unger raises to dismiss an unrelated reason to be suspicious of this premiss to do with our having non-epistemic reasons to believe].

19 Wright agrees this is a further constraint any response to Scepticism must meet.
} 
if you've numbed your ears, doesn't this overt, explicit fallibillism still sound wrong? (Lewis 1996, p. 550) 20

The trouble, as Lewis continues, is that if we reject Fallibilism, Scepticism seems to be lurking round the corner. So we need some way of threading a course "between the rock of fallibilism and the whirlpool of scepticism" (Lewis 1996, p. 655). And Lewis' proposal as to how we should do this is of course to accept Contextualism: briefly, the view that the semantic value of the word 'knowledge' depends on the context in which it is used (c.f. also Cohen 1988; DeRose 1995).

As it has turned out, Contextualism has not been all that popular. There are many different kinds of complaint against it; some, I think, pretty apposite, some not so much. I am not about to try to assess the relative merits of all those misgivings, and their possible rebuttals. However, the trouble with Contextualism, (in particular in light of Lewis' plea) it seems to me, is this: Contextualism can only address issues about the 'knowledge', where the Sceptical challenge is to knowledge, not the word 'knowledge' - 'He knows, yet he has not eliminated all possibilities of error' sounds mad because knowledge is infallible. To see this, consider that according to Lewis, Contextualists must accept that knowledge is "elusive" (it "disappears" when you try to capture it).

I said that when we do epistemology, and we attend to the proper ignoring of possibilities, we make knowledge vanish. First we do know, then we do not. But I had been doing epistemology when I said that. The uneliminated possibilities were not being ignored - not just then. So by what right did I say even that we used to know? (Lewis 1996, p. 566).

This makes it look like there is after all a heavy price to pay for going Contextualist (so is not quite the panacea Lewis at first makes out), viz. that our theorising about knowledge can only ever tell us something about how we use 'knowledge' in the contexts in which we theorise about it. But that is surely not why many of us (at least!) investigate knowledge. There seems to be something akin to navel-gazing in extremis about wanting to make discoveries about the way a word is used in the knowledge that those discoveries are relevant only in the context of seeking those very discoveries. ${ }^{21}$ And Lewis' solution to this issue, in the last couple of sentences of "Elusive Knowledge", just underscores that Contextualism cannot answer the Sceptical challenge when the latter addresses knowledge, and not merely the word 'knowledge':

I could have said my fair and square, bending no rules. It would have been tiresome, but it could have been done. The secret would have been to resort to 'semantic ascent'. I could have taken great care to distinguish between (1) the language I use when I talk about knowledge, and (2) the second language that I use when I talk about the semantic and pragmatic workings of the first language. (Lewis 1996, p. 556-7).

\footnotetext{
20 See also Hetherington $(2012,2016)$.

21 For a similar criticism, cf. Sosa (2000).
} 
To resort to 'semantic ascent' to resolve the puzzle is effectively to concede that the object of investigation in epistemology is an object in the first-order language that the meta-language would purport to describe. And to heed the need to resort to semantic ascent here is to admit that there may be something that is motivating theorising about knowledge beyond an interest in the workings of the word 'knowledge': if we think it's problematic that results from an investigation about knowledge would apply only relative to a theoretical context, via parity of reasoning it's also reasonably natural to think it problematic these results would apply only relative to a given first-order language. If, however, the madness intuition that Lewis describes is one that is directed at a thing in the world (knowledge) then speakers must be making some kind of a mistake (though maybe not strictly a linguistic mistake) when they use 'knows' in a context where the possibility of error is not salient, but exists (even if this is not a semantic or pragmatic mistake in a given language relative to a context). This is captured by RETREAT. The subjects in these cases do not, strictly speaking, know. Nevertheless, even if that is conceded, there seems to be something right about saying that they do know in these contexts. Can the defender of RETREAT account for this?

Here we can usefully avail ourselves of a Warranted Assertability Manoeuvre (an appeal to Gricean pragmatic implicature). We can deploy a WAM here as follows: For most speakers of English, the distinction between knowledge and justified belief is not sharply (if at all) made in ordinary use. So many will acknowledge some difference when prompted, but will think that it is really just as good to say 'knowledge' when they mean 'justified belief', except in some very particular cases. For ordinary speakers it is mostly (but not always) indeterminate whether it is correct to use 'knowledge' or 'justified belief' (or some variant of the latter) and mostly it is correct to use either. In ordinary conversational contexts, then, when we utter the word 'knowledge' referring to a subject in contexts where the possibility of error for the subject is not salient but exists, we also pragmatically convey that the subject to which we're attributing knowledge has a justified belief. ${ }^{22}$ But this is also the case when we utter the word 'knowledge' referring to a subject in a context where the possibility of error for the subject is salient. ${ }^{23}$ It isn't that we just cannot be bothered to make ourselves more clear-we don't really think there is reason to do so. Because we pragmatically convey that the subject has a justified belief in these cases, we capture the feeling that they've not altogether got it wrong. This is predicted by RETREAT, since adhering to it is to maintain that justification need not be infallible and so compatible with the possibility of error, salient or otherwise. So RETREAT has the resources to explain why it seems to us that there is something not altogether incorrect about using knowledge locutions

\footnotetext{
22 This is explained, I think, by the Gricean maxim of relation: be relevant! (Perhaps also by the maxim of manner: the subject making the assertion, knowing how his interlocutor will take her locution wants to be as brief as possible, and so does not need to explain that she really means justified belief, as opposed to knowledge. This will be the case for an epistemologist talking to a non-philosopher maybe-since the distinction not well understood outside of philosophy)

23 The reason I say this is pragmatic and not semantic is that if DIVORCE then the concept knowledge is logically independent from the concept of justification. However, as I say, for many speakers this is not an open question: you've got as much evidence as is required for you to be justified in believing that $p$, but do you know that $p$ ? 'Knowledge' just means 'justified belief' for these speakers.
} 
when there is possibility of error, but why it seems that doing so is nevertheless a mistake (albeit not necessarily a linguistic one).

But mustn't we explain why knowledge locutions seem like more of a mistake when uttered in contexts where the possibility of error has been made salient? Yes. But an explanation is close at hand for the proponent of RETREAT. It is simply this: the mistake will seem more obtuse, or more like a culpable mistake when the possibility of error has been acknowledged, or is so salient that it ought to be acknowledged. If I say that $\mathrm{S}$ knows that $p$, and I'm not aware of some possibility that $\mathrm{S}$ might be mistaken about $p$, then I'm making a mistake to be sure, but it's a mistake that we can live with. Conversely, when I say "S knows that $p$, but it is possible that not $-p$ " then my use of the word 'knows' seems to be a rather more culpable mistake (since I obviously am aware of the possibilities of error). The difference between 'knowledge' and 'justified belief' is not a sharp one in ordinary language, but that does not mean that there are not some clear cases where-again in ordinary language - something like 'jusitifed belief' (or something equally meant as hedging) and not 'knowledge' is appropriate.

Dovetailing this point nicely, I think, is the fact that we only have the "madness" intuition with respect to locutions involving knowledge and not with locutions involving justification. It seems perfectly natural (and not mad at all) to say: "He's justified in believing it, but has not eliminated all possibilities of error". If justification were sufficient for knowledge then we would have expected it to sound as mad. But it does not, so we have pro tanto reason at least to think that justification is not sufficient for knowledge. Further, if we think that justification (however it is to be cashed out) is warrant, i.e. is the thing that makes the difference between true belief and knowledge, then we should also expect it to sound as mad. But it does not sound as mad, so this gives us pro tanto reason to believe that justification is not necessary for knowledge (where justification is thought to be the thing that makes the difference between true belief and knowledge). And, yet further, if we think that justification is not the alchemic thing that "turns" true belief into knowledge, then we should ask what justification is really there to do. More precisely, we should ask what phenomenon our theories of justification are there to capture. If we can't give an account of this without invoking something that will end up being identical (or close to identical) to what I've been calling the "deontic intuition", then my previous argument for DIVORCE will return to bite.

For all these reasons, then, I think that we can take on board Lewis' argument for Infallibilism - that it is madness to deny it-without having to accept either Scepticism about epistemic justification or Contextualism. There has, however, been another alternative put on the table-Subject Sensitive Invariantism (SSI) - which perhaps can deliver a similar result. I'll now address SSI in the section that follows.

\section{The argument from Purism ('no' to pragmatic encroachment)}

In this section, I am going to argue that a very influential argument put forward in support of Subject Sensitive Invariantism (SSI) vindicates Infall $\mathrm{k}_{\mathrm{k}}$.

SSI is the view that while the semantic values of the word 'knows' (and its correlates) are not context sensitive (hence 'invariantism'), the standards determining 
whether one knows (not 'knows') can vary depending on the practical circumstances of the subject doing the knowing.

A very influential — and to my mind pretty formidable — argument in favour of SSI is one articulated by Fantl and McGrath (2009). In paraphrase, it goes as follows:

(i) If Purism - the denial of SSI—-then Infallibilism. [Premise]

(ii) If Infallibilism then Scepticism. [Premise]

(iii) Scepticism is false. [Premise]

(iv) Infallibilism is false. [From ii, iii]

(v) Purism is false. [From iii, ii]

Fantl and McGrath's central efforts go into defending (i). Their idea is that if Fallibilism is true, then $\mathrm{S}$ can know that $p$ even when the epistemic probability of $p$ (for $\mathrm{S}$ ) is not 1 . But this surely does not mean that $\mathrm{S}$ knows that $p$ no matter what the epistemic probability (for $\mathrm{S}$ ) is that $p$. But then the following threshold problem arises: how can we determine what is the epistemic probability for $\mathrm{S}$ that $p$ required for $\mathrm{S}$ to know that $p$ ? Fantl and McGrath argue that the best answer involves looking at whether the assigned probability "can be properly put to work as a basis for belief and action" (Fantl and McGrath 2009, p. 25). But this is incompatible with Purism, since whether or not an assigned epistemic probability value (for $\mathrm{S}$ ) can be properly put to work as a basis for belief and action (by S) will co-vary with how much is at stake for $\mathrm{S}$ as regards the relevant belief or action. If little is at stake the probability need not be as high as when a lot is at stake.

Fantl and McGrath work hard to show how their solution to the threshold problem is superior to alternative solutions offered by Contextualists, and by employing WAMs. I am not here going to evaluate their work-my argument for Infall $\mathrm{k}_{\mathrm{k}}$ that follows is predicated on the proposition that Fantl and Grath have succeeded in showing that the best solution (compatible with Fallibilism) to the threshold problem is incompatible with Purism. ${ }^{24}$ Here is my argument:

(ii*) If Infallibilism then unacceptable Scepticism (unless RETREAT).

(i) If Purism then Infallibilism.

(vi) Purism.

(vii) RETREAT [from i*, ii, vi]

(viii) If RETREAT then Infall $_{k}$ is true and Infall $j_{j}$ is false.

(ix) Infall $k .[$ From vii, viii]

The two central premises I need to defend in the above argument are (ii*) (the move from ii to ii*), and ix. Let me start with my defence of moving from ii to ii*. Here I can once again mobilise the arguments in favour of RETREAT that I levied in Sect. 3. However, Fantl and McGrath will presumably want to resist RETREAT, given that it seems to violate a principle they use to motivate SSI. Along with other defenders of SSI, that is, they advocate a principle connecting knowledge and action, such that (roughly) if you know that $p$ then it is permissible for you to act on $p$ (cf. Stanley 2005; Hawthorne and Stanley 2008). Fantl and McGrath think this principle can be extended such that it covers justified belief as well as action-that if you know that

${ }^{24}$ For dissention, cf. Brown (2014). 
$p$, it follows that you are justified in believing that $p$; in their formulation (where $\varphi$ covers beliefs as well as actions):

(KJ) If you know that $p$, then $p$ is warranted enough to justify you in $\varphi$-ing, for any $\varphi$. (Fantl and McGrath 2009, p. 66).

Their case for $\mathrm{KJ}$ is that it can be derived from the following two principles:

(KR) If you know that $p$, then $p$ is warranted enough to be a reason you have to $\varphi$, for any $\varphi$. (Fantl and McGrath 2009, p. 69; cf. also Unger 1975, Hawthorne and Stanley 2008).

[Safe Reasons] If $p$ is a reason you have to $\varphi$, then $p$ is warranted enough to justify you in $\varphi$-ing, for any $\varphi$. (Fantl and McGrath p. 77).

KJ seems to be inconsistent with RETREAT, given the Sceptical challenge, since it seemingly violates DIVORCE. Why might KJ be thought to violate DIVORCE? According to Fantl and McGrath ${ }^{25}$ it does for the following reason:

Suppose, for reductio, that both KJ and radical externalism are true. Then there is a possible subject who knows that $p$ with strong justification for not-p and at best extremely weak justification for $p$. By KJ, $p$ is warranted enough to be a justifier for this subject. By radical externalism, the subject has a true belief which meets the relevant externalist conditions. Each of these factors - truth, belief, and the externalist conditions - is such that subtracting it makes no difference to whether $p$ is warranted enough to justify. But, if all these are subtracted, the subject is left with nothing in the way of warrant that could allow $p$ to justify. Yet the subtractions don't affect whether $p$ is warranted enough to justify the subject, and since it is warranted enough to justify in the case of knowledge, it is still warranted enough to justify when all is gone. Contradiction. (Fantl and McGrath 2009, p. 106).

Luckily, I do not think that the fact that KJ can be derived from KR and Safe Reasons poses a problem for the defender of DIVORCE, since I think she can easily resist the relevant reading of 'justify' in Safe Reasons and KJ (I'm working with a version of Safe Reasons such that it is restricted to belief.) Now, according to Fantl and McGrath, the support for Safe Reasons comes from the fact that when "we weight reasons we have, we do so without taking into account the relative probabilities (or more generally the weaknesses in warrant) of respective reasons" (Fantl and McGrath 2009, p. 77). The point is that it is supposed to be consistent with Safe Reasons that having a reason to believe that $p$ can be defeated by another reason (undercutting or rebutting or whatever). So here we're working with a notion of pro tanto justification: the reason is warranted enough to justify, but it might not justify all things considered or pro toto; the reason gives us pro tanto, and not pro toto, justification to have a given belief.

\footnotetext{
25 In a passage where they deal with an objection coming from what they call "radical externalism" ("this is a clean and simple view: knowledge is one thing, justification another; the two can vary wildly from one another" p. 104) according to which justification is not necessary for knowledge: "can the radical externalists hold on to KJ? We don't think so" p. 106.
} 
That is clearly the sense of 'justified' that is at work in KJ. But in DIVORCE-as I have defended it - the notion of justification is a deontological concept about freedom from appropriate blame, and so about pro toto, or all things considered justification (not pro tanto justification). ${ }^{26}$

Fantl and McGrath claim:

...there is a possible subject who knows that $p$ with strong justification for not-p and at best extremely weak justification for $p$

But here they are equivocating on 'justification' as they are using the above to determine that DIVORCE is incompatible with KJ. According to the proponent of DIVORCE, the possible subject who knows that $p$ has a strong pro tanto justification for $p$, but weak pro toto justification for $p$, and strong pro toto justification that not- $p$. Since DIVORCE does not rule-out the entailment between knowing that $p$ and having protanto justification to believe that $p$, DIVORCE is, after all, compatible with KJ.

Now onto my defence of (viii). We have Purist intuitions about knowledge. These intuitions are made salient, especially I think, when we consider that if Purism is false, then what MacFarlane (2005) has called "knowledge laundering" is possible. But we intuitively baulk at the idea that knowledge laundering is possible. For instance, suppose that knowledge transmits through testimony, and that the stakes as regards that $p$ are very low for a friend, but they are very high for me. Suppose then that my evidence as regards $p$ falls short of knowledge, since the fact that the stakes are high for me has made it the case that the evidential bar is quite high. However, that bar is lower for my friend, given the fact that the stakes are low for him. In giving my friend my evidence for $p$, I would make it the case that my friend knows that $p$. My friend could then impart that knowledge back to me via testimony, and I would also know that $p$. But our intuitions rebel. We pre-theoretically don't want to say that I know that $p$ in this case.

Fantl and McGrath do acknowledge the force of Purist intuitions, but think they must be overcome given the cost of denying Fallibilism, viz. Scepticism. As they put it, the arguments against purism are "strong enough that we can learn to live with the oddities" (2009, p. 210). However, clearly, endorsing a theory that enables you to evade the most problematic Sceptical conclusions, while not having to learn to live with having to overcome the oddities that arise form denying Purism, is a preferable alternative. And this is precisely what RETREAT promises, since notice that our intuitions about transmission of knowledge through testimony across high-stake-lowstake contexts are intuitions about knowledge. We do not seem to baulk-at least not as much —when we consider correlate cases about justification (especially if we consider them while keeping in mind DIVORCE). It just does not seem so infelicitous to say:

- "I am justified in believing that $p$, but a minute ago, when the stakes were higher, I was not justified in believing that $p$, even though I had the same evidence."

- "I am justified in believing that $p$, but, had the stakes been higher and my evidence the same, I would not be justified in believing that $p . "$

\footnotetext{
26 For an argument as to why deontological justification involves pro toto and not pro tanto reasons and duties see Booth (2012).
} 
- "I am justified in believing that $p$, but Mary and John are not justified in believing that $p$, even though I have the same evidence as they do."

- "I am justified in believing that $p$, but I cannot impart my justified belief that $p$ to Bob by telling him that $p$, even though he has no special reason to doubt my sincerity or my reliability."

If we insert 'know that $p$ ' in lieu of 'justified in believing that p', our intuitions rebel. This is evidence, I take it, that our Purist intuitions are about knowledge not justification. I accept that Purism about knowledge entails Infallibilism so long as we are careful to note that Purism about knowledge does not entail Infall $\mathrm{j}_{\text {. }}$. And as I have argued, Infall $\mathrm{k}_{\mathrm{k}}$ does not entail a worrying Scepticism if RETREAT (assuming DIVORCE). Thus, if we accept RETREAT, we can take on board our Purist intuitions while handling Scepticism. This is good reason to accept RETREAT, and ex hypothesi, Infall $_{\mathrm{k}}$.

\section{Conclusion}

Proponents of Infalliblism have often made their case via the thesis that knowledge is closed under entailment. Famously, this has led many to embrace a thorough-going Scepticism (Unger, in particular, is a case in point). By 'thorough-going' I mean the kind of Scepticism that takes no refuge in a Russellian Retreat. In so far as I have managed to make persuasive some new (or under-represented) considerations in favour of Infallibilism to those who wish to abstain from such a thorough-going Scepticism (and correlatively do so without having to take a stand on the minefield of closure), this paper has its success gauged accordingly. ${ }^{27}$

Open Access This article is distributed under the terms of the Creative Commons Attribution 4.0 International License (http://creativecommons.org/licenses/by/4.0/), which permits unrestricted use, distribution, and reproduction in any medium, provided you give appropriate credit to the original author(s) and the source, provide a link to the Creative Commons license, and indicate if changes were made.

\section{References}

Adler, J. (2002). Belief's own ethics. MA: Cambridge MIT Press.

Bonjour, L. (2003). Epistemic justification. Oxford: Blackwell.

Booth, A. R. (2011). The theory of epistemic justification and the theory of knowledge: A divorce. Erkenntnis, 75(1), 37-43.

Booth, A. R. (2012). All things considered duties to believe. Synthese, 187(2), 1867-1880.

Booth, A. R. (2014). The Gettier illusion, the tripartite analysis, and the divorce thesis. Erkenntnis, 79(3), $625-638$.

Brown, J. (2014). Impurism, practical reasoning, and the threshold problem. Noûs, 48(1), 179-192.

Cohen, S. (1988). How to be a fallibilist. Philosophical Perspectives (Epistemology), 2, 91-123.

DeRose, K. (1995). Solving the sceptical problem. Philosophical Review, 104(1), 1-52.

Dodd, D. (2007). Why Williamson should be a sceptic. Philosophical Quarterly, 57(229), 635-649.

\footnotetext{
27 With thanks to two anonymous referees for Synthese, Corine Besson, Job de Grefte, Bob Lockie, Aidan McGlynn, Michael Morris, and Murali Ramachandran for comments and discussion on earlier drafts of this piece.
} 
Dodd, D. (2011). Against fallibilism. Australasian Journal of Philosophy, 89, 665-685.

Fantl, J., \& McGrath, M. (2009). Knowledge in an uncertain world. Oxford: Oxford University Press.

Foley, R. (2004). A trial separation between the theory of knowledge and the theory of justified belief. In J. Greco (Ed.), Sosa and his critics. Oxford: Wiley.

Hawthorne, J., \& Stanley, J. (2008). Knowledge and action. Journal of Philosophy, 105(10), 571-590.

Hetherington, S. (2012). The Gettier illusion: Gettier partialism and infallibilism. Synthese, 188, 217-230. Hetherington, S. (2016). Knowledge and the Gettier problem. Cambridge: Cambridge University Press.

Huemer, M. (2007). Moore's paradox and the norm of belief. In S. Nuccetelli \& G. Seay (Eds.), Themes from G.E. Moore. Oxford: Oxford University Press.

Kaplan, M. (1985). It's not what you know that counts. Journal of Philosophy, 82(7), 350-363.

Kelp, C. (2011). Not without justification. Dialectica, 65, 581-595.

Kvanvig, J. (2014). Rationality and reflection: How to think about what to think. Oxford: Oxford University Press.

Lewis, D. (1996). Elusive knowledge. Australasian Journal of Philosophy, 74(4), 549-567.

Littlejohn, C. (2008). From E = K to scepticism? Philosophical Quarterly, 58(223), 679-684.

Littlejohn, C. (2012). Justification and the truth-connection. Cambridge: Cambridge University Press.

Littlejohn, C. (2013). The Russellian retreat. Proceedings of the Aristotelian Society, 3(3), 293-320.

Lockie, B. (2014). The regulative and the theoretical in epistemology. Abstracta, 8(1), 3-14.

MacFarlane, J. (2005). Knowledge laundering: Testimony and sensitive invariantism. Analysis, 65, 132-138.

McGlynn, A. (2012). Interpretation and knowledge maximization. Philosophical Studies, 160, 391-405.

McGlynn, A. (2013). Believing things unknown. Nô̂s, 47, 385-407.

Neta, R. (2011). A refutation of cartesian fallibilism. Nô̂s, 45, 658-695.

Pritchard, D. (2005). Epistemic luck. Oxford: Oxford University Press.

Pritchard, D. (2007). Anti-luck epistemology. Synthese, 158, 287-297.

Russell, B. (1912). The problems of philosophy. London: Williams \& Norgate.

Sorensen, R. (1988). Blindspots. New York: Oxford University Press.

Sosa, E. (2000). Skepticism and contextualism. Philosophical Issues, 10, 1-18.

Stanley, J. (2005). Knowledge and practical interests. New York: Oxford University Press.

Sutton, J. (2005). Stick to what you know. Noûs, 39, 359-396.

Sutton, J. (2007). Without justification. Cambridge, MA: MIT Press.

Unger, P. (1975). Ignorance: A case for scepticism. Oxford: Clarendon Press.

Williamson, T. (2000). Knowledge and its limits. Oxford: Oxford University Press.

Wright, C. (1991). Scepticism and dreaming: Imploding the demon. Mind, 100, 87-116.

Zagzebski, L. (1994). The inescapability of gettier problems. The Philosophical Quarterly, 44, 65-73. 